\title{
Impact of Authentic Leadership Style on Job \\ Satisfaction: Case of Insurance Sector in Bosnia and Herzegovina
}

\author{
Ajana Šakić \\ Department of Management, International Burch University \\ Francuske Revolucije bb, 71000 Sarajevo, Bosnia and Herzegovina \\ E-mail: ajanasakic@gmail.com
}

\begin{abstract}
Nereida Hadžiahmetović (Corresponding Author)
Department of Management, International Burch University

Francuske Revolucije bb, 71000 Sarajevo, Bosnia and Herzegovina

E-mail: nereida.hadziahmetovic@ibu.edu.ba
\end{abstract}

Natasa Tandir

Department of Management, International Burch University

Francuske Revolucije bb, 71000 Sarajevo, Bosnia and Herzegovina

E-mail: natasa.tandir@ibu.edu.ba

Received: Jan. 14, 2019 Accepted: Feb. 11, 2019 Online published: Feb. 19, 2019

doi:10.5296/ijhrs.v9i1.14225 URL: https://doi.org/10.5296/ijhrs.v9i1.14225

\begin{abstract}
Managing good employees in the current competitive business environment is one of the difficulties an organization is facing in order to accomplish their objectives. Having in mind that employees' feelings, spirit regarding the job, commitment and engagement are among the biggest factors that should never be overlooked by the organization. All of these factors as well as their reactions to various aspects of the job and organization will seriously affect employees' performance, involvement and engagement. Organizational leadership is one of the vital factors in all organizations as well as one of the key strategies to accomplish this
\end{abstract}


purpose. This research inspects and tests the influence of authentic leadership style on employees' satisfaction with their jobs in insurance companies from Bosnia and Herzegovina. Many industries and organizations, in particular the insurance industry, can benefit by this research with different advantages: learn about the enhancement and advantages of authentic leadership, suggestions for workers fulfillment and how authentic leadership can impact employees' motivation and engagement. Regression analysis was conducted to test the hypothesis. Results indicate that authentic leadership style has significant effect on employees' job satisfaction.

Keywords: authentic leadership style, job satisfaction, insurance companies

\section{Introduction}

Leadership in any organization needs to be authentic in order to be effective and more successful in a long term (Hassan \& Ahmed, 2011). Different leaders, research scholars from across the world from the ancient times have emphasized on the ethics and authenticity for organization's leaders, in order to get more accurate and effective governance (Hassan \& Ahmed, 2011). Leadership of every organization needs to show the standards of morality in every talk, decisions and behavior, which can be helpful in the smooth flow of organization. Authentic leaders always show a high level of integrity and have sense of purpose and commitment to their core values. These leaders can help firms fulfill the needs of shareholders and other stakeholders. As a result, these kinds of leaders create healthy relationship among the work groups which result in several positive outcomes, such as, employee engagement, employee intention to stay, organizational commitment, job satisfaction, etc. (Hassan \& Ahmed, 2011). As per the discussion of Gardner, B.J, \& Walumbwa (2005), followership is the most important component of leadership and the followers always expect that leader's authenticity must be developed through time. As a result, by keeping the positive role of leaders, authentic leadership serves as an important component for the improvement of authentic followers.

The rest of the paper is organized in six sections. The next section provides theoretical background regarding authentic leadership and job satisfaction. The third section develops model and hypothesis, where the fourth section explains the applied research methodology. The fifth and sixth sections provides results and discussion, respectively. The seventh section concludes the paper.

\section{Theoretical Background}

\subsection{Leadership}

History has been investigating its leaders from the beginning of the time and leadership is still an active inquiry area. Leadership is often the most important factor in the success or failure of institutions (Bass, B., 1990). Burns, J.M. (1978) has stated that "Leadership is one of the most observed and least understood phenomena on earth". The discussion of leadership as a process have been described by Machiavelli in the sixteenth century (Smith, et al. 1989). However, it has been advanced by Max Weber at the beginning of the last century. According to Weber (1946), leadership rests on three possible types of authority: charismatic 
authority, reflected personal characteristics; traditional authority, referred to compliance with norms and forms of conduct; and legal authority, which resulted from functional ,duty of office $^{\text {ec }}$. The study of leadership that began in the twentieth century was initially concerned with leaders' effectiveness. Leadership has been defined in terms of traits, behavior, influence, interaction patterns, role relationships, and occupation of an administrative position (Yukl, G., 2002).

Leadership has different meaning to various authors, where some have interpreted leader in simple terms as influencers, who knows the art of influencing people, so they will endeavor readily and excitedly towards accomplishment of group goals. Leadership is the act of making things happen rather than letting things happen (Nwachuckwu, C.C., 1988). A true leader does this by exerting both intrinsic and extrinsic influences on the group. The leader interacts with people and therefore leadership is the most visible among all management functions. Some of the keywords best describing leadership would be: directly commanding, guiding, inspiring, initiating and activating. Eventually, it all comes to a relation through which one person influences the behavior of other people.

From the many leadership definition, three most important implications should be mentioned. Firstly, leadership is a process engaged by certain individual (leader). It is an ongoing activity in an organization. Secondly, it includes other individuals as subordinates who by their eagerness are affected by the leader. Therefore, these subordinates formalize the leader's authority by making leadership process possible. Thirdly, the aim of leadership is the accomplishment of a goal and objectives.

Despite numerous definitions of leadership, a frequently cited component is the concept of "influence". Tannenbaum (1961) defines the leadership as "interpersonal influence exercised in a situation and directed, through the communication process, toward the attainment of a specialized goal or goals".

\subsection{Importance of Leadership in the Organizational Context}

There are numerous researches and theories which define leadership and its importance within an organization. Considering different studies, organizational commitment and job satisfaction are profoundly related, hence they can affect turnover. Dissatisfied employees do not perform well and are neither motivated nor focused to effectively achieve authoritative objectives and goals. Thus, they are emotionally and rationally unsatisfied with their work and look for other work opportunities (Crawford \& Lok, 2004).

For an organization, it is essential to know its human resource needs and develop its leaders and followers. As indicated by Chemers, (1997), leadership obliges productive utilization of accessible resources which are accomplished in two layers:

1) every staff member should viably utilize the individual resources, for example, knowledge, inventiveness, abilities and information, 
2) leaders arrange and allocate resources by taking into account the needs of the organization so that all resources are used in the most effective manner (Sandra \& Dimovski, 2013).

Leaders can impact organizational culture through their authority and based on what behavior they choose to model that later turns into the vital part of the organization (Bass, B., 1990). As indicated by Gardner, Avolio, \& Walumbwa (2005), organizations ought to offer equivalent open doors for everybody for learning and developing, in this way they ought to give open access information, support, and resources. Such a working environment would enable leaders and followers to work more efficiently and feel more engaged, where accordingly, they would easily adapt to the changing environment.

\subsection{Definition of Authentic Leadership}

Authentic leadership was firstly defined by Luthans \& Avolio, (2003) as a "process that draws from both positive psychological capacities and a highly developed organizational context, which results in both greater self-awareness and self-regulated positive behaviors on the part of leaders and associates, fostering positive self-development."

Gardner, W., L., et al., (2005) tried to incorporate all of the different views and definitions by proposing a self-based model of authentic leader and follower development. This model is focused on the authentic leadership components of self-awareness and self-regulation. The modern researchers define authentic leadership as a model of leader behavior which encourages positive self-development and influence followers' attitudes and behaviors (Walumbwa et al., 2008). Hence, there exists a process which links the behavior and attitude of employers with authentic leadership (Avolio, et al., 2004).

Authentic leadership creates such an environment where confidence increases, followers are supported in work and in establishment of their strengths, value is added in decision making and within the organization, the performance is constantly developed (Avolio, et al., 2004). There is a common agreement on the four elements of authentic leadership such as: self-awareness, internalized moral perspective, balanced processing and relational transparency (Avolio, Weber \& Walumbwa, 2009).

\subsection{Job Satisfaction}

Human resource management (HRM) is the management of decisions and actions related with the employees in the organization who contribute to the achievement of organization's objectives. HRM should be concerned strategically, since, it maintains employee satisfaction. Employees are more loyal and productive when they are satisfied, and satisfied employees affect the customer satisfaction and organizational productivity (Potterfield, T., 1999). Employee satisfaction is defined as the combination of what he/she wants to receive compared with what he/she actually receives. The organizations should try to fulfil employees' expectations in order to improve the employee satisfaction. In addition, emotional conditions of the employees may likewise influence their satisfaction, therefore, managers should aim to make and sustain the desired working environments in the organizations. Although job satisfaction is under the influence of numerous external factors, it remains 
something internal that has to do with the way how the employee feels. Job satisfaction and job dissatisfaction can appear in any random given work situation. It is commonly seen to be directly connected to productivity as well as to individual prosperity. Despite the fact that satisfaction is usually linked to motivation, these two are not the same. Job satisfaction is more of an attitude, an internal state. It could, for example, be associated with a personal feeling of achievement, either quantitative or qualitative (Mullins, J.L., 2005). Job satisfaction can be considered as one of the main factors when it comes to efficiency and effectiveness of business organizations.

The term job satisfaction refers to the attitude and feelings people have about their work. Positive and favorable attitudes towards the job indicate job satisfaction. Negative and unfavorable attitudes towards the job indicate job dissatisfaction (Armstrong, M., 2006). Job satisfaction is the collection of feeling and beliefs that people have about their current job. Moreover, negative and unfavorable attitudes towards the job indicate job dissatisfaction (Armstrong, M., 2006). The significance of job satisfaction specially emerges to surface if many negative consequences of job dissatisfaction such as: lack of loyalty, increased absenteeism, increased number of accidents etc., is considered.

Job satisfaction is categorized in 2 main groups: intrinsic and extrinsic job satisfaction. Intrinsic job satisfaction regards employees' expectations from their jobs and impact their attitudes towards their jobs, where extrinsic job satisfaction occurs due to external factors such as physically appropriate working environment, being a part of a coherent team, being appreciated by colleagues and superiors, receiving a reward, and improving professional career.(Lee, 2017).

\section{Conceptual Framework and Hypothesis Development}

This paper aims to demonstrate empirically and theoretically, the influence of authentic leadership on satisfaction of employees in a particular organization. Avolio, et al. (2004), suggest that authentic leaders have the abilities to improve the employee motivation, their engagement, job satisfaction, commitment and the involvement, so that they might improve their performance results by the creation of personal identification with subordinates and social identification with the firm.

Authentic leadership is generally considered to be composed of 4 concepts: self - awareness, transparency, balanced processing of information, internalized moral perspective (Walumbwa et al., 2008).

Some previous studies have investigated the impact of authentic leadership style on job satisfaction. Azanza, Moriano, \& Molero, (2013) studied authentic leadership as a driver of employees' job satisfaction. The study was conducted on 571 employees from several Spanish private firms. Other study by Wong \& Laschinger, (2013) found that employees are satisfied with their job if managers are more seen as authentic by highlighting self-awareness, transparency, high moral norms, and balanced processing. Avolio, B., J. et al, (2004) investigated how authentic leaders impact follower behaviors, performance and attitudes. Leroy, Anseel, Gardner, \& Sels, (2015) conducted a survey research on Belgian service companies, they found a positive relationship between authentic leadership and authentic 


\section{Macrothink}

International Journal of Human Resource Studies

ISSN 2162-3058 2019, Vol. 9, No. 1

followership and follower basic need satisfaction. Miniotaitè \& Bučiūnienè, (2013) stated that authentic leadership increases intrinsic motivation, employee commitment and job satisfaction. In addition, the intrinsically oriented employees are more involved in authentic leader-follower relations, from employees who prefers extrinsic work values. Yidong \& Xinxin, (2013) explored mediating role of intrinsic motivation between ethical leadership and employees' innovative work behavior in China, where results showed that employees intrinsic motivation mediate this relationship. Empirical research conducted by Majauskaite \& Alonderiene, (2015) in Lithuanian universities found that leadership styles have impact on job satisfaction. Moreover, it is found that servant leadership style has the strongest impact, on the other side the autocratic leadership has the lowest impact on job satisfaction.

Following hypotheses were developed based on given literature:

H1: Authentic leadership has significant positive effect on extrinsic job satisfaction.

$\mathrm{H} 2$ : Authentic leadership has significant positive effect on intrinsic job satisfaction.

H3: Authentic leadership has significant positive effect on general job satisfaction.

A research model shown in [Figure 1] conceptualizes the authentic leadership factors into 4 dimensions of self-awareness, internalized moral perspective, balanced processing of information, and relational transparency to empirically test what kinds of effect does each factor have on job satisfaction of employees in insurance sector.

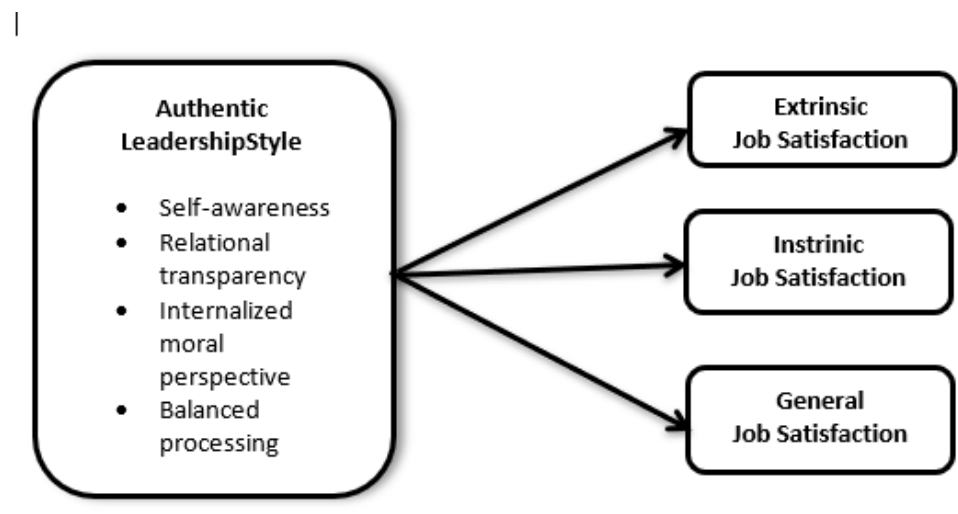

Figure 1. Research model

\section{Research Method}

\subsection{Target Population and Sample}

The target population in this research are employees in insurance companies. The study participants are employed and under the supervision of a leader. The leader's style will have impact on the way of how workers contribute to the company's goals. From 201 respondents who participated in this study, 53,2\% were females and 46,8\% were males. Biggest number of employees was under the age of 34 , working for 1 to 3 years at the same position. 


\section{Mll Macrothink}

International Journal of Human Resource Studies

ISSN 2162-3058 2019, Vol. 9, No. 1

Managers were in most cases over 40 years of age, working in multiple departments of insurance companies.

\subsection{Questionnaire Design}

The study examined the concept of job satisfaction among 201 employees in different positions. Participants rated their leaders via the Authentic Leadership Questionnaire (ALQ short) and their own job satisfaction via Minnesota Satisfaction Questionnaire (MSQ - short) (Abugre, 2014), and completed a short, demographic questionnaire through online platform.

The MSQ - short contains 20 items; intrinsic job satisfaction is measured by 12 items, extrinsic job satisfaction is measured by six items, and general job satisfaction is measured by 20 items. The ALQ contains 16 scales measuring four first - order factors (self - awareness, relational transparency, internalized moral perspective and balanced processing); the four factors combine to provide a perceived second - order factor called authentic leadership. Statistical data processing was carried out using programs such as Excel and SPSS.

\section{Results}

Total of 201 respondents participated in this study, 53,2\% were females and 46,8\% were males. The respondents below 25 years of age comprise $26,9 \%$ of the total number, those 25 to 34 years $30,8 \%$, those 35 to 54 years $37,3 \%$, and 55 and over group had 5,0\% of subjects. In total 86 subjects had bachelor's degree $(42,8 \%)$, furthermore, 76 subjects $(37,8 \%)$ had master's degree. Only $0,5 \%$ were students while $1 \%$ had $\mathrm{PhD}$ degree. In addition, 36 participants $(17,9 \%)$ had only high school diploma. Most of the participants have been at current position between 1-3 years $(48,3 \%)$. 83 respondents $(41,3 \%)$ worked at current position for 4 to 10 years. 18 participants were on same position for 11 to 20 years, and only 3 participants were on same position for more than 20 years. This information is in direct correlation with age distribution of participants, while largest part of participants were younger employees. Cronbach's alpha analysis was conducted on responses. Cronbach's Alpha for Intrinsic Job Satisfaction was found to be 0,887, for Extrinsic job satisfaction 0,883 and for General job satisfaction 0,852. Moreover, Cronbach's Alpha value for Authentic Leadership characteristics was 0,873 .

Table 1. Correlation between ALS and job satisfaction

\begin{tabular}{c|l|l|l|l|l}
\hline \multicolumn{2}{c|}{} & ALS & IJS & EJS & GJS \\
\hline \multirow{4}{*}{ ALS } & Pearson Correlation & 1 & .662 & .704 & .574 \\
\cline { 2 - 6 } & Sig. (2-tailed) & &, 000 &, 000 &, 000 \\
\cline { 2 - 6 } & N & 201 & 201 & 201 & 201 \\
\hline \multirow{4}{*}{ IJS } & Pearson Correlation & $.662^{\cdots \cdots}$ & 1 & .890 & .808 \\
\cline { 2 - 6 } & Sig. (2-tailed) &, 000 & &, 000 &, 000 \\
\cline { 2 - 6 } & N & 201 & 201 & 201 & 201 \\
\hline \multirow{4}{*}{ EJS } & Pearson Correlation & $.704^{* \cdots}$ & .890 & 1 & $.872^{\cdots \cdots}$ \\
\cline { 2 - 6 } & Sig. (2-tailed) &, 000 &, 000 & &, 000 \\
\cline { 2 - 6 } & N & 201 & 201 & 201 & 201 \\
\hline \multirow{4}{*}{ GJS } & Pearson Correlation & .574 & .808 & .872 & 1 \\
\cline { 2 - 6 } & Sig. (2-tailed) &, 000 &, 000 &, 000 & \\
\cline { 2 - 6 } & N & 201 & 201 & 201 & 201 \\
\hline
\end{tabular}




\section{Macrothink}

International Journal of Human Resource Studies

ISSN 2162-3058 2019, Vol. 9, No. 1

This study tested for correlations between authentic leader characteristics and different job satisfaction types. ALS had positive significant moderate correlation with general job satisfaction $(0,574, \mathrm{p}<0,001)$, where it had strong correlation with intrinsic job satisfaction $(0,662, \mathrm{p}<0,001)$. Moreover, Extrinsic job satisfaction and ALS had positive significant strong correlation of $0,704, p<0,001$.

Multivariate analysis of variance (MANOVA) is an extension of the univariate analysis of variance (ANOVA). In this study one-way MANOVA test was used to determine whether there are any differences between independent groups on more than one continuous dependent variable.

Table 2. Multivariate tests

\begin{tabular}{|c|c|c|c|c|c|c|c|c|c|}
\hline \multicolumn{10}{|c|}{ Multivariate Tests ${ }^{\mathrm{a}}$} \\
\hline \multicolumn{2}{|c|}{ Effect } & \multirow{2}{*}{$\begin{array}{l}\text { Value } \\
, 934\end{array}$} & \multirow{2}{*}{$\begin{array}{c}\mathrm{F} \\
794.57\end{array}$} & \multirow{2}{*}{$\begin{array}{c}\begin{array}{c}\text { Hypothesis } \\
\text { df }\end{array} \\
3,00\end{array}$} & \multirow{2}{*}{$\begin{array}{r}\text { Error df } \\
168,00\end{array}$} & \multirow{2}{*}{$\begin{array}{l}\text { Sig. } \\
, 000\end{array}$} & \multirow{2}{*}{$\begin{array}{c}\begin{array}{c}\text { Partial } \\
\text { Eta } \\
\text { Squared }\end{array} \\
, 934\end{array}$} & \multirow{2}{*}{$\begin{array}{c}\text { Noncent. } \\
\text { Parameter } \\
2383,71\end{array}$} & \multirow{2}{*}{$\begin{array}{c}\begin{array}{c}\text { Observed } \\
\text { Power }^{\mathrm{d}}\end{array} \\
1,000\end{array}$} \\
\hline \multirow{4}{*}{ Intercept } & $\begin{array}{l}\text { Pillai's } \\
\text { Trace }\end{array}$ & & & & & & & & \\
\hline & $\begin{array}{l}\text { Wilks' } \\
\text { Lambda }\end{array}$ & ,066 & 794.57 & 3,00 & 168,00 & ,000 & ,934 & 2383,71 & 1,000 \\
\hline & $\begin{array}{c}\text { Hotelling's } \\
\text { Trace }\end{array}$ & 14,189 & 794.57 & 3,00 & 168,00 &, 000 & ,934 & 2383,71 & 1,000 \\
\hline & $\begin{array}{c}\text { Roy's } \\
\text { Largest } \\
\text { Root } \\
\end{array}$ & 14,189 & 794.57 & 3,00 & 168,00 &, 000 & ,934 & 2383,71 & 1,000 \\
\hline \multirow{4}{*}{ ALS } & $\begin{array}{l}\text { Pillai's } \\
\text { Trace }\end{array}$ & ,911 & 2,470 & 90,0 & 510,00 & ,000 & ,304 & 222,34 & 1,000 \\
\hline & $\begin{array}{c}\text { Wilks' } \\
\text { Lambda }\end{array}$ & ,274 & 3,025 & 90,0 & 503,65 & ,000 & ,350 & 271,38 & 1,000 \\
\hline & $\begin{array}{l}\text { Hotelling's } \\
\text { Trace }\end{array}$ & 2,014 & 3,730 & 90,0 & 500,00 & ,000 & , 402 & 335,679 & 1,000 \\
\hline & $\begin{array}{c}\text { Roy's } \\
\text { Largest } \\
\text { Root }\end{array}$ & 1,682 & $9.534^{c}$ & 30,0 & 170,00 & ,000 & ,627 & 286,011 & 1,000 \\
\hline
\end{tabular}


Table 3. Tests of between subjects effects

\begin{tabular}{|c|c|c|c|c|c|c|c|c|c|}
\hline \multicolumn{2}{|l|}{ Source } & $\begin{array}{l}\text { Type III } \\
\text { Sum of } \\
\text { Squares }\end{array}$ & df & $\begin{array}{l}\text { Mean } \\
\text { Square }\end{array}$ & $\mathrm{F}$ & Sig. & $\begin{array}{l}\text { Partial } \\
\text { Eta } \\
\text { Squared } \\
\end{array}$ & $\begin{array}{l}\text { Noncent. } \\
\text { Parameter }\end{array}$ & $\begin{array}{l}\text { Observed } \\
\text { Power }^{\mathrm{d}}\end{array}$ \\
\hline \multirow{3}{*}{$\begin{array}{l}\text { Corrected } \\
\text { Model }\end{array}$} & IJS & $78.841^{\mathrm{a}}$ & 30 & 2,628 & 7,609 & ,000 & ,573 & 228,256 & 1,000 \\
\hline & EJS & $108.820^{\mathrm{b}}$ & 30 & 3,627 & 8,724 & ,000 & ,606 & 261,733 & 1,000 \\
\hline & GJS & $114.279^{c}$ & 30 & 3,809 & 4,676 & ,000 & ,452 & 140,286 & 1,000 \\
\hline \multirow{3}{*}{ Intercept } & IJS & 761,197 & 1 & 761,197 & 2203,772 & ,000 & ,928 & 2203,772 & 1,000 \\
\hline & EJS & 753,636 & 1 & 753,636 & 1812,642 & , 000 & ,914 & 1812,642 & 1,000 \\
\hline & GJS & 717,780 & 1 & 717,780 & 881,127 & ,000 & ,838 & 881,127 & 1,000 \\
\hline \multirow{3}{*}{ ALS } & IJS & 78,841 & 30 & 2,628 & 7,609 & ,000 &, 573 & 228,256 & 1,000 \\
\hline & EJS & 108,820 & 30 & 3,627 & 8,724 &, 000 & ,606 & 261,733 & 1,000 \\
\hline & GJS & 114,279 & 30 & 3,809 & 4,676 &, 000 &, 452 & 140,286 & 1,000 \\
\hline \multirow{3}{*}{ Error } & IJS & 58,719 & 170 &, 345 & & & & & \\
\hline & EJS & 70,680 & 170 & ,416 & & & & & \\
\hline & GJS & 138,485 & 170 & 815 & & & & & \\
\hline \multirow{3}{*}{ Total } & IJS & 1421,882 & 201 & & & & & & \\
\hline & EJS & 1396,889 & 201 & & & & & & \\
\hline & GJS & 1389,500 & 201 & & & & & & \\
\hline \multirow{3}{*}{$\begin{array}{l}\text { Corrected } \\
\text { Total }\end{array}$} & IJS & 137,560 & 200 & & & & & & \\
\hline & EJS & 179,500 & 200 & & & & & & \\
\hline & GJS & 252,764 & 200 & & & & & & \\
\hline
\end{tabular}

a. R Squared $=, 573$ (Adjusted R Squared $=, 498$ )

b. R Squared $=, 606$ (Adjusted R Squared $=, 537$ )

c. R Squared $=, 452$ (Adjusted R Squared $=, 355)$

d. Computed using alpha $=.05$

Wilks Lambda had value of 0,274 with $F$ of 3,025 with significance level of $p<0,001$. It can be concluded that managers characteristics had influence on job satisfaction. In Table 3 , it can be seen that IJS had sig. $=0,82$ ( $p>0,05)$, therefore it can be concluded that it did not have strong influence on IJS. Extrinsic job satisfaction was influenced on level of $p=0,015$. ALS could describe about $57 \%$ of IJS $\left(\mathrm{R}^{2}=0,573, \mathrm{p}<0,001\right)$, also it had described $60,6 \%$ of EJS $\left(\mathrm{R}^{2}=0,606, \mathrm{p}<0,001\right.$ and $45,2 \%$ of GJS $\left(\mathrm{R}^{2}=0,452, \mathrm{p}<0,001\right)$.

Based on these results, we have accepted hypotheses that authentic leadership style has a significant impact on job satisfaction. We have accepted hypothesis that authentic leadership style has significant impact on general job satisfaction, also on extrinsic job satisfaction and intrinsic job satisfaction. It had biggest correlation with extrinsic job satisfaction.

\section{Discussion}

During analyses of given answers couple of questions were about manager's behavior: Manager asks for feedback in order to improve his/her interaction with a companion in $59,7 \%$ of cases, $48,3 \%$ participants agrees with statement that manager care about other people's 
perception about him. Participants have agreed that manager is outspoken in $53,7 \%$ cases, with $28,35 \%$ who don't have opinion. With statement that manager solicits views that could challenge his/her held position mostly subjects disagree $(44,3 \%)$. This goes in favor of statement that managers, even workers in general don't like to go against company policy. Only $38,65 \%$ of participants believe that managers decisions are made based on core beliefs. With $36,3 \%$ of those who don't have opinion nor are against, could lead us to opinion that managers decisions are very calculated. Manager beliefs are consistent with actions in 50,2\% of the cases. This number could be bigger, but 31,3\% doesn't agree or disagree with statement. In comparison to that, $36,3 \%$ of participants don't agree with statement that manager admits his mistakes, however, $27,3 \%$ doesn't agree or disagree. In total $44,7 \%$ agrees that manager is patient to listen carefully different opinions before coming to conclusion. It is found that $30,8 \%$ doesn't agree or disagree with statement, and $24,5 \%$ disagrees. In total there is around $50 \%$ of chance that manager won't have enough patience to listen employees.

The analyses found that $66,2 \%$ of participants are mostly busy all the time with 50,8\% participant who have a chance to do different things from time to time. Almost half of participants are working every day same things, with the possible appearance of monotony that could impact on job satisfaction. A chance to work alone have 51,1\% of participant, but we must remember that in this study CEOs were also included, and chief staff also. This goes in favor of statement that $42,3 \%$ of the subjects have chance to be somebody in the community. Doing things that went against personal conveniences was an issue in $63,1 \%$ of participant, and they weren't able to do those things. In addition, stable employment had $49,3 \%$ of participants, also $30,8 \%$ didn't agree or disagree with this statement. During the work time $59,2 \%$ had a chance to do things for other people, on other side $57,7 \%$ had a chance to do something that make use of their abilities. Authority could express $44,8 \%$ of participant, while $18,9 \%$ didn't agreed or disagreed.

Company polices were put into practice in appropriate way at $52,8 \%$ of subjects, but biggest number of responders in our study didn't agree or disagree $(32,8 \%)$. Freedom to use own judgement had $53,3 \%$ of respondents while $27,9 \%$ didn't agree or disagree. This could also be tested with the position in the company. Similar doubt is presented with statement that worker has a chance to try his/her own methods of doing job: 57,2\% have agreed with statement, while $17 \%$ have disagreed. Wage satisfaction was present in 53,8\% of cases. Only $33(16,9 \%)$ have disagreed with this statement. This is one of the major questions in job satisfaction. Analyzing correlation between wage satisfaction and company's position, we have concluded that those who have agreed with this statement are on better-paid jobs. Similar number of $43,3 \%$ had a chance to advance in career, while $11,4 \%$ have disagreed with this statement. Working conditions were adequate for good job performance in $60,2 \%$ of responders, while $15,5 \%$ have disagreed. Further investigation has revealed that those were lower paid positions. This brings about job dissatisfaction as employees are not motivated to try their own ways of doing things for the fear that they will be reprimanded based on showing disrespect and being "too known". This is in consonance with Blake E. Ashforth, (1990) findings that perceived lack of opportunity to have an impact on the organization may 
possibly lead to job dissatisfaction of employees and ultimately a high turnover rate. This finding is also consistent with Kuada, (2010) assertion that most African employees have the inclination of following every aspect of their superiors' instructions at the detriment of their own creativity. Consequently, it is not surprising that findings of this study further showed only $4 \%$ and $7 \%$ of respondents reporting "satisfied" and "very satisfied," respectively, for "the feeling of accomplishment I get from the job." The findings showed that over $50 \%$ of respondents are dissatisfied and de-motivated because they never accomplish what they want from their jobs. Coworkers get along with each other was statement on which $1 / 4$ did not have opinion. But 54,4\% had agreed with it. Praise on work was reported in 57,7\% of cases, but $17,4 \%$ didn't agree. Around $80 \%$ have agreed with statement that they got accomplishment when doing good job.

\subsection{Further Research}

This research has been conducted on only one sector (insurance companies) with limited number of participants. Future researches can investigate several other sectors such as banking, hotels and restaurants sectors. Moreover, this research can be extended to geographically different locations, and the obtained results can be compared.

\section{Conclusion}

Overall, in this study we had determined the aspects of authentic leadership that affect employee's job satisfaction in insurance sector in Bosnia and Hercegovina. This study is about understanding the effects of the leader's authentic leadership on the employee's job satisfaction. Scientifically, this research contributes to further development of understanding of the relationship between factors of authentic leadership and employee satisfaction. Practically, this research may help some insurance companies to improve their business from the aspect of employee satisfaction generated by good leadership styles. Manager characteristics are having huge impact on every type of job satisfaction.

\section{References}

Abugre, J. B. (2014). Job Satisfaction of Public Sector Employees in Sub-Saharan Africa: Testing the Minnesota Satisfaction Questionnaire in Ghana. International Journal of Public Administration, 37(10), 655-665. https://doi.org/10.1080/01900692.2014.903268

Armstrong, M. (2006). A Handbook of Human resource Management Practice (Tenth edition). Kogan Page Publishing, London.

Avolio, B. J., Gardner, W. L., Walumbwa, F., Luthans, F., \& May, D. R. (2004). Unlocking the mask: A look at the process by which authentic leader's impact follower attitudes and behaviors. In The Leadership Quarterly, 15(6), 801 - 823.

Avolio, B. J., Weber T. J., \& Walumbwa, F. O. (2009). Leadership: Current theories, research, and future directions. In Annual Review of Psychology, 60(1), 421 - 449.

Azanza, G., Moriano, J. A., \& Molero, F. (2013). Authentic leadership and organizational culture as drivers of employees' job satisfaction. Revista de Psicología del Trabajo y de las 
Organizaciones, 29(2).

Retrieved

from

http://www.redalyc.org/resumen.oa?id=231328684001

Bass, B. (1990). From Transactional to Transformational Leadership: learning to share the vision. Organizational Dynamics, (1990).

Blake, E., \& Ashforth, B. W. G. (1990). The Double-Edge of Organizational Legitimation. Organization Science.

Burns, J. M. (1978). Leadership (2nd ed.). HarperCollins Publishers.

Chemers, M. M. (1997). An integrative theory of leadership. Mahwah, N.J: Lawrence Erlbaum Associates.

Crawford, J., \& Lok, P. (2004). The effect of organisational culture and leadership style on job satisfaction and organisational commitment: A cross-national comparison. Journal of Management Development, 23(4), 321-338. https://doi.org/10.1108/02621710410529785

Gardner, W. B. J. A., \& Walumbwa. (2005). Authentic leadership development: emerging theme and future directions. (2005).

Gardner, W. L., Avolio, B. J., Luthans, F., May, D. R., \& Walumbwa, F. (2005). Can you see the real me? A self - based model of authentic leader and follower development. In The Leadership Quarterly, 16(3), 343 - 372.

Hassan, A., \& Ahmed, F. (2011). Authentic Leadership, Trust and Work Engagement. International Journal of Economics and Management Engineering, 5(8), 7.

Kuada, J. (2010). Culture and leadership in Africa: a conceptual model and research agenda. African Journal of Economic and Management Studies, 1(1), 9-24. https://doi.org/10.1108/20400701011028130

Lee, T. (2017). Relationship Between Intrinsic Job Satisfaction, Extrinsic Job Satisfaction, and Turnover Intentions Among Internal Auditors. Walden Dissertations and Doctoral Studies. Retrieved from https://scholarworks.waldenu.edu/dissertations/3354

Leroy, H., Anseel, F., Gardner, W. L., \& Sels, L. (2015). Authentic Leadership, Authentic Followership, Basic Need Satisfaction, and Work Role Performance: A Cross-Level Study. Journal of Management, 41(6), 1677-1697. https://doi.org/10.1177/0149206312457822

Luthans, F., \& Avolio, B. J. (2003). Authentic Leadership: A Positive Developmental Approach. In K. S. Cameron, J. E. Dutton, \& R. E. Quinn (Eds.), Positive organizational scholarship: foundations of a new discipline (1st ed). San Francisco, CA: Berrett-Koehler.

Majauskaite, M., \& Alonderiene, R. (2015). Leadership style and job satisfaction in higher education institutions. International Journal of Educational Management, 30(1), 140-164. https://doi.org/10.1108/IJEM-08-2014-0106

Miniotaitè, A., \& Bučiūnienè, I. (2013). Explaining authentic leadership work outcomes from the perspective of self-determination theory. Management of Organizations: Systematic 
Research, 65(65), 63-75. https://doi.org/10.7220/MOSR.1392.1142.2013.65.5

Mullins, J. L. (2005). Management and organizational behavior (Seventh edition). Pearson Education Limited, Essex.

Nwachuckwu, C. C. (1988). Personnel administration in Nigeria, University of port-harcourt press, Nigeria.

Potterfield, T. (1999). The business of employee empowerment: Democracy and ideology in the workplace. Westport, Conn, Greenwood Publishing Group.

Sandra, \& Dimovski. (2013). Leadership development in cross-cultural team: Evidence from Confucius institute Ljubljana.

Smith, P. B., Misumi, J., Tayeb, M., Peterson, M., \& Bond, M. (1989). On the generality of leadership style measures across cultures*. Journal of Occupational Psychology, 62(2), 97-109. https://doi.org/10.1111/j.2044-8325.1989.tb00481.x

Tannenbaum, M. (1961). Leadership and Organization. A behavioral science approach. Pp. xiv. 456. New York : McGraw-Hill Book Co., 1961.

Walumbwa, F. O., Avolio, B. J., Gardner, W. L., Wernsing, T. S., \& Peterson, S. J. (2008). Authentic Leadership: Development and Validation of a Theory-Based Measure $\dagger$. Journal of Management, 34(1), 89-126. https://doi.org/10.1177/0149206307308913

Weber, M. (1946). From Max Weber: Essays in sociology:: bahasa melayu. New York: Oxford university press.

Wong, C. A., \& Laschinger, H. K. S. (2013). Authentic leadership, performance, and job satisfaction: the mediating role of empowerment. Journal of Advanced Nursing, 69(4), 947-959. https://doi.org/10.1111/j.1365-2648.2012.06089.x

Yidong, T., \& Xinxin, L. (2013). How Ethical Leadership Influence Employees' Innovative Work Behavior: A Perspective of Intrinsic Motivation. Journal of Business Ethics, 116(2), 441-455. https://doi.org/10.1007/s10551-012-1455-7

Yukl, G. (2002). Leadership in Organizations (5th edition). International, New Jersey: Prentice Hall, Upper Saddle River, N.J.

\section{Copyright Disclaimer}

Copyright for this article is retained by the author(s), with first publication rights granted to the journal.

This is an open-access article distributed under the terms and conditions of the Creative Commons Attribution license (http://creativecommons.org/licenses/by/4.0/). 